\title{
BURNOS HIGIENISTŲ NUOMONĖ APIE APNAŠO KAUPIMĄSI PRIE SKIRTINGŲ RESTAURACIJŲ IR JO ŠALINIMO BŪDUS
}

\author{
Edita Valkiūnaitė, Asta Varaškevičienė, Daiva Mačiulienė \\ Kauno kolegijos Medicinos fakultetas, Burnos sveikatos katedra
}

Raktažodžiai: burnos higienistų nuomonè, apnašo kaupimasis prie skirtingų restauracijų, apnašo šalinimo būdai.

\begin{abstract}
Santrauka
Straipsnyje pristatomo tyrimo tikslas - atskleisti burnos higienistų nuomonę apie apnašo kaupimąsi prie skirtingų restauracijų ir jo šalinimo būdus. Tyrime dalyvavo 125 burnos higienistai. Taikytas duomenu rinkimo metodas - apklausa raštu. Atlikto tyrimo rezultatai parodè, kad dalis burnos higienistų teigia nepastebintys, jog apnašas kaupiasi skirtingai prie skirtingų restauracinių medžiagų. Didžioji dalis apklaustujų pastebi skirtingą jo kaupimąsi. Išanalizavus tyrimo duomenis nustatyta, kad burnos higienistų, pastebinčiu apnašo pokytị prie skirtingų restauracijų, nuomonę apie apnašo kaupimąsi daugiausia nulemia praktinè veikla. Respondentai, nepastebintys apnašo pokyčio prie skirtingų restauracijų, nurodo, jog tokiai jų nuomonei didžiausią įtaką daro kolegų patirtis. Beveik pusė burnos higienistų, pastebinčių apnašo pokyti prie skirtingų restauracijų, naudoja tinkamus, plastikinius ir tefloninius, instrumetus, kai dirba prie keramikinių restauracijų paviršiaus. Priešingus rezultatus pateikè respondentai, nepastebintys apnašo pokyčių, didžioji dalis jų teigè, jog naudoja tuos pačius instrumentus kaip ir prie nuosavų dantų paviršių. Gauti tyrimo rezultatai rodo, kad daugiau nei pusė respondentų, pastebinčių apnašo pokytį prie skirtingų restauracijų, naudoja gliciną. Daugiau nei puse burnos higienistų, teigusių, jog nepastebi apnašo pokyčio prie skirtingų restauracijų, nurodo, kad poliruodami restauracijas oro abrazijos būdu naudoja natrio bikarbonatą. Didžioji dalis burnos higienistų, pastebinčių apnašo pokytị prie skirtingų restauracijų, mano, kad subraižytas restauracijos paviršius turi įtakos didesnei bakterijų adhezijai. Daugiau nei pusè burnos higienistų, pažymejusių, jog nepastebi apnašo pokyčio prie skirtingų restauracijų, teigia, kad subraižymas turi įtakos estetiniam dantų vaizdui.
\end{abstract}

Ivadas

Šiandieninëje odontologijoje dantų gydymui bei jų priežiūrai keliami vis aukštesni reikalavimai, tad ir pacientai atvyksta į odontologijos kabinetą su vis didesniais lūkesčiais. Dẻl nuolatos didèjančių estetinių reikalavimų štampuoti metaliniai vainikèliai bei amalgamos restauracijos yra išstumiamos iš šiandieninès rinkos ir pakeičiamos tiesioginemis bei netiesioginėmis kompozicinèmis restauracijomis ar keramikos ịklotais, užklotais [1]. Kai kuriais atvejais atsitinka taip, kad danties nepavyksta išsaugoti ir jị tenka šalinti. Tuomet, norint atkurti prarasto danties defektą, pasirenkama dantų implantacija. Praejjus kuriam laikui ant ịsriegtosios ị kaulą dalies gaminamas dantų vainikèlis, kuris labai ilgai atlieka restauracinès medžiagos funkciją [3]. Susikaupę maisto likučiai, nepašalintas apnašas, išsivystęs èduonis - tai eiga to, kas paskatina įvairius procesus, kad mūsų burnos ertmèje atsirastų restauracinių medžiagų. Tačiau kaip iki tol apnašas kaupèsi ant dantų, taip ir juos pakeitus restauracijomis apnašas kaupiasi toliau. Skirtingos restauracinès medžiagos turi nevienodą cheminę sudètị, tai lemia didesnị ar mažesnị paviršiaus šiurkštumą, o tai nulemia intensyvesnį ar silpnesnị bakterijų tvirtinimąsi [4]. Idealiu atveju restauracija, pagaminta laboratorijoje, neturètų reikalauti jokių pakeitimų, kai ji ịdedama ị paciento burną. Tačiau dažnai dèl paciento patogumo restauracijos okliuzija yra koreguojama ịvairiais grąžteliais, kurie šiurkština vainikèlio paviršių ir padidina bakterijų sukibimo galimybę [12]. Besikaupiantis apnašas laikui bėgant formuoja vis didesnes bakterijų kolonijas. Tam, kad šis nepasiektų dantenų bei periodonto audinių ir nesukeltų uždegiminių procesų, jị būtina šalinti tiek individualios higienos, tiek profesionalios higienos metu [2]. Atliekant profesionalią burnos higienos procedūrą su netinkamais instrumentais restauracijų paviršius gali būti subraižomas ir bakterijų adhezija po procedūros yra gerokai padidinama nei buvo prieš atliekant procedūrą. Todèl labai svarbu žinoti, kaip tinkamai pašalinti besikaupiantị apnašą ant restauracinių medžiagų, suteikti pacientui informacijos, kaip tinkamai prižiūrèti restauracijas namuose, kad šios kuo ilgiau išliktų kokybiškos, ir informuoti, kokių veiksmų reikia vengti, kad 
nebūtų pagreitintas bakterijų akumuliacijos procesas [4].

Tyrimo tikslas: atskleisti burnos higienistų nuomonę apie besiformuojantį apnašą prie skirtingų restauracinių medžiagų bei jo šalinimo būdus.

\section{Tyrimo objektas ir metodika}

Tyrimas vyko $2018 \mathrm{~m}$. balandžio - gegužès mèn. Internetinè anketos nuoroda su kvietimu dalyvauti apklausoje publikuota Lietuvos burnos higienistų draugijos internetinèje svetaineje. Tyrimo metu naudotas duomenų rinkimo metodas - apklausa raštu, tyrimo instrumentas - internetiné anketa. Anketą sudare 25 klausimai. Tyrime dalyvavo 125 burnos higienisto išsilavinimą turintys asmenys, iš kurių 124-moterys ir 1 vyras. Didžioji dalis respondentų (67\%) dirba valstybinèse odontologijos klinikose. Dauguma atsakiusiųjų (80\%) turi iki 5metų stažo (1 lentelè).

\section{Tyrimo rezultatai}

Tyrimo rezultatai atskleidè, kad didžioji dalis apklaustujų $(64,8 \%)$ teigia pastebintys, jog apnašas kaupiasi skirtingai prie skirtingų restauracinių medžiagų, beveik penktadalis apklaustujų $(23,2 \%)$ teigia, jog tokio skirtingo apnašo kaupimosi jie nepastebi, mažoji dalis respondentų (11,2\%) tik kartais pastebi apnašo pokytị prie restauracijų (1 paveikslas).

Tyrimo metu nustatyta, kad tiek respondentų, pastebinčiuc skirtingą apnašo kaupimąsi, tiek respondentų, nepastebinčių skirtingo apnašo kaupimosi, nuomonę labiausiai lemia praktiné veikla (atitinkamai 43,8 \% ir 45,7 \%). Tyrimo rezultatai atskleidè, kad didesnioji dalis respondentų, nepastebinčių apnašo kaupimosi $(51,4 \%$ ), yra linkę pasikliauti kolegų nuomone, o didesnioji dalis burnos higienistų, kurie pastebi skirtingo apnašo kaupimąsi (15,3 \%), dažniau remiasi literatūros analize. Pastebèta, kad burnos higienistai, kurių nuomonei ịtakos turi konferencijų metu gauta informacija, labiau linkę pastebèti apnašo kaupimąsi (21 \%) (2 pav.).

1 lentelè. Demografiniai respondentų duomenys (proc.) $(\mathrm{N}=125)$.

\begin{tabular}{|c|c|}
\hline \multicolumn{2}{|c|}{ Demografiniai respondentų duomenys } \\
\hline \multicolumn{2}{|l|}{ Apklaustujų skaičius - 125} \\
\hline \multicolumn{2}{|l|}{ Lytis, n (\%) } \\
\hline Moteris / Vyras & $124(99,2 \%) / 1(0,8 \%)$ \\
\hline \multicolumn{2}{|l|}{ Darbovietè, n (\%) } \\
\hline $\begin{array}{l}\text { Valstybinė odontologijos klinika/ } \\
\text { Privati odontologijos klinika/ } \\
\text { Valstybiné ir privati odontologijos } \\
\text { klinikos }\end{array}$ & $\begin{array}{l}47(37,6 \%) / \\
67(53,6 \%) / \\
11(8,8 \%)\end{array}$ \\
\hline \multicolumn{2}{|c|}{ Praktinis burnos higienisto darbo stažas, n (\%) } \\
\hline $\begin{array}{l}\text { Iki } 5 \text { metu/ } \\
\text { Nuo } 5 \text { iki } 10 \text { metų/ } \\
\text { Daugiau nei } 10 \text { metul }\end{array}$ & $\begin{array}{c}100(80 \%) / \\
19(15,2 \%) / \\
6(4,8 \%)\end{array}$ \\
\hline
\end{tabular}

Dèl atsirandančių mikroịtrūkimų, įskilimų, plombos susitraukimo, paliktų kabančių plombos kraštų daugiausia apnašo kaupia tiesioginès restauracijos - dantų plombos, lyginant su netiesioginemis restauracijomis: dantų implantais, keramikos restauracijos, prie kurių apnašas kaupiasi mažiau [5-7]. Respondentai, pastebintys apnašo pokytị prie skirtingų restauracijų, atsake, kad, jų nuomone, daugiausia apnašo kaupiasi prie dantų plombų: $22,4 \%$. Kitokią nuomonę išreiškè respondentai, nepastebintys apnašo pokyčių prie skirtingų restauracijų. Jų teigimu, labiausiai apnašas kaupiasi prie metalo keramikos restauracijų, taip nurodo daugiau nei pusė apklaustujų - 64,8\% (3 pav.).

Literatūroje [8] atkreipiamas dėmesys ị tai, kad šalinant susikaupusį apnašą nuo keramikinių restauracijų, mažiausiai paviršių subraižo varinis ultragarsinio skalerio antgalis. Dirbant su juo mažeja galimybè, jog po procedūros bus dar labiau padidinama bakterijų adhezija dèl subraižyto restauracijos paviršiaus. Apklausos rezultatai rodo, jog daugiau nei trečdalis respondentų $(39,5 \%)$, pastebinčių apnašo pokytị prie skirtingų restauracijų, tinkamiausiu skalerio antgaliu laiko nerūdijančio plieno antgalị. Daugiau nei pusė apklaus-

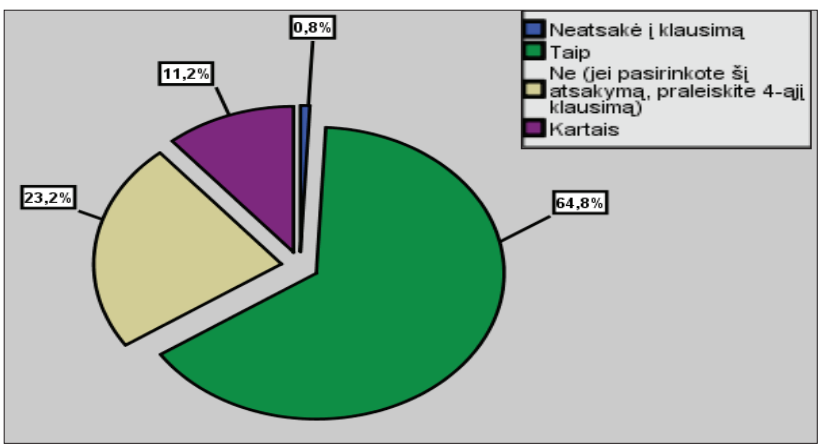

1 pav. Respondentų pasiskirstymas pagal pastebimą apnašo pokytị prie restauracijų (proc). $(\mathrm{N}=125)$.

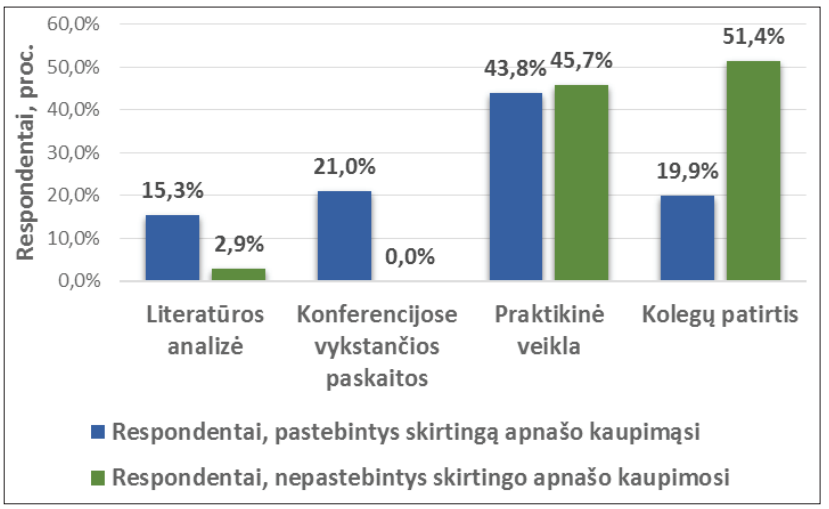

2 pav. Respondentų pasiskirstymas pagal tai, kokie veiksniai lemia jų nuomonę apie apnašo kaupimąsi (proc.) $(\mathrm{N}=110)$. 


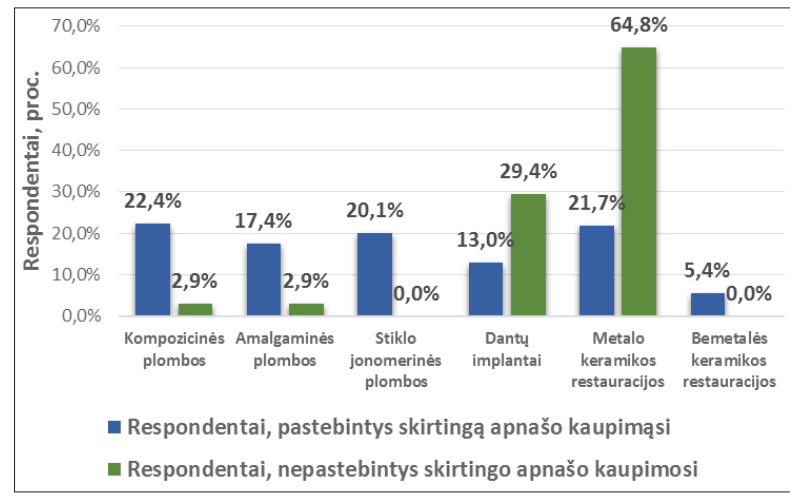

3 pav. Respondentų pasiskirstymas pagal tai, kuri restauracija, ju nuomone, kaupia daugiausiai apnašo (proc.) $(\mathrm{N}=110)$.

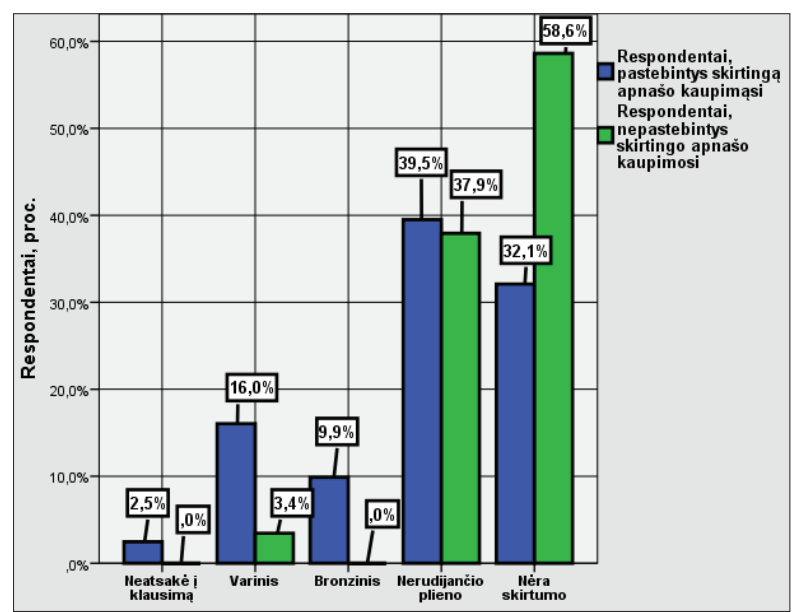

4 pav. Respondentų pasiskirstymas pagal tai, koks, jų nuomone, yra tinkamiausias antgalis dirbant prie keramikos restauraciju (proc.) $(\mathrm{N}=110)$.

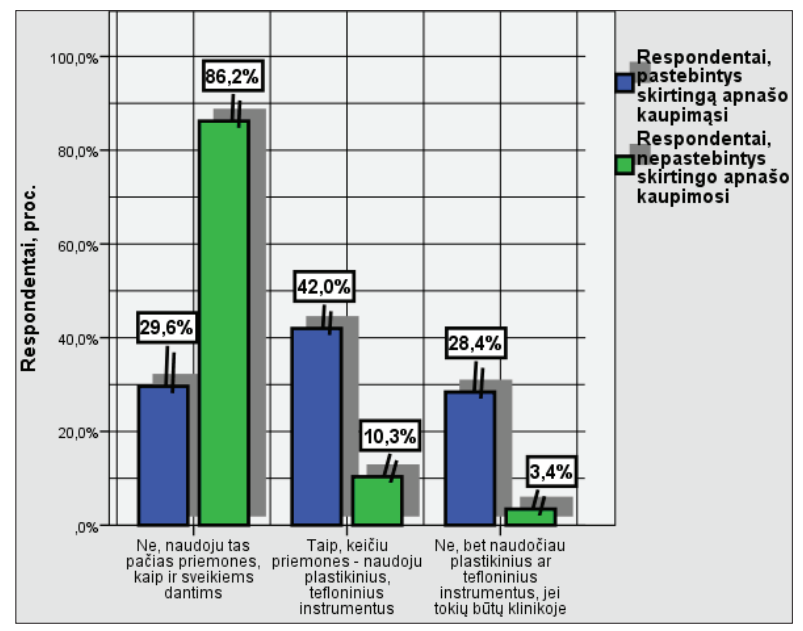

5 pav. Respondentų pasiskirstymas pagal tai, kokius darbo įrankius jie pasirenka dirbdami prie keramikos restauracijų (proc.) $(\mathrm{N}=110)$.

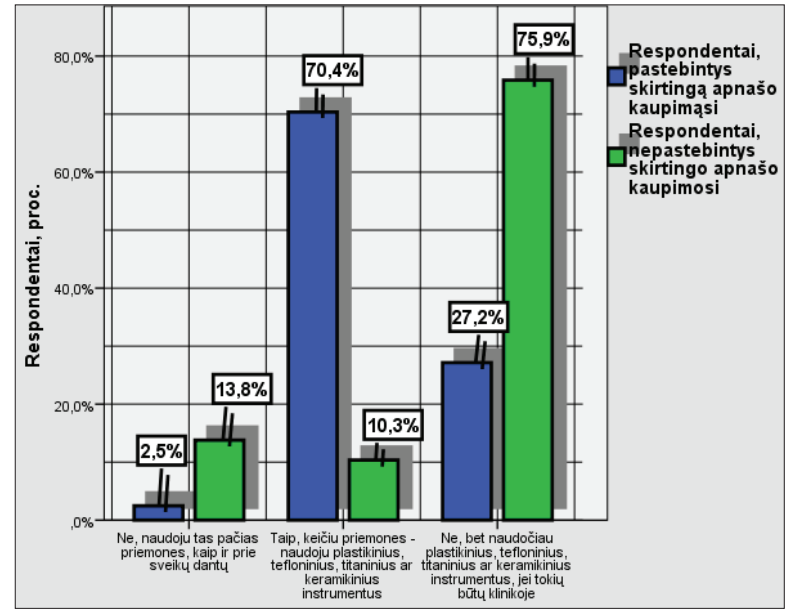

6 pav. Respondentų pasiskirstymas pagal tai, kokius darbo įrankius jie pasirenka dirbdami prie dantų implantų (proc.) $(\mathrm{N}=110)$.

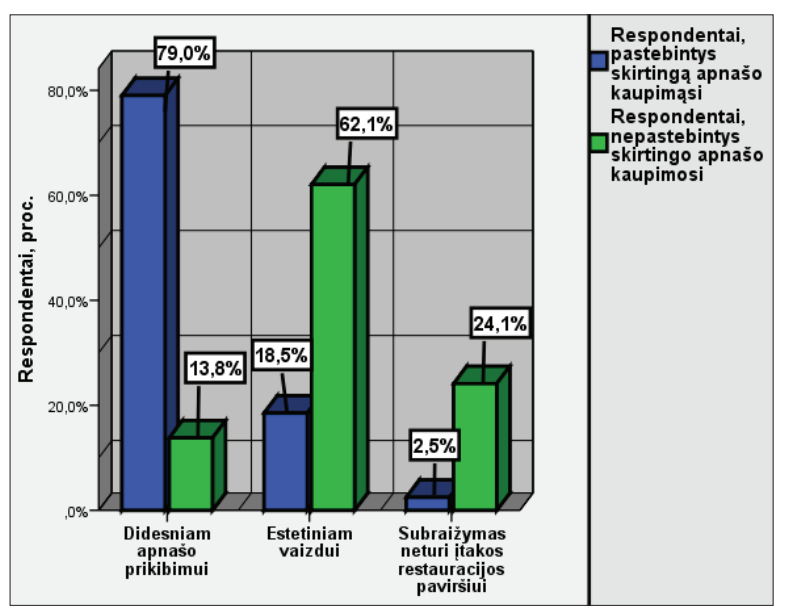

7 pav. Respondentų pasiskirstymas pagal tai, kokios, jų nuomone, gali būti subraižytų restauracijų pasekmès (proc.) $(\mathrm{N}=110)$.

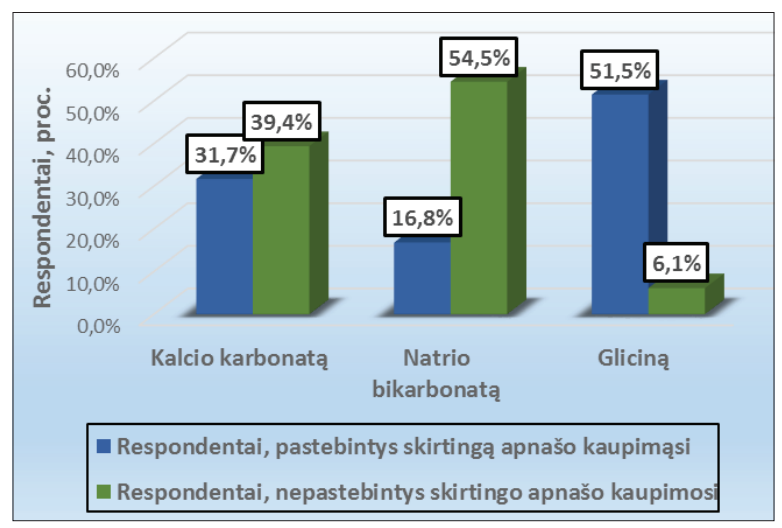

8 pav. Respondentų pasiskirstymas pagal tai, kokią medžiagą jie naudoja poliruodami restauracijas oro abrazijos būdu (proc.) $(\mathrm{N}=110)$. 
tujų (58,6 \%), nepastebinčių apnašo pokyčio prie skirtingu restauracijų, rinkosi atsakymą, jog nèra skirtumo su kokiu skaleriu yra dirbama prie keramikinių restauracijų (4 pav.).

Literatūros apžvalgoje $[4,9]$ nurodoma, jog tinkami rankiniai intsrumentai svarbūs dirbant ne tik prie dantų implantų, bet ir prie keramikinių restauracijų. Siekiant kuo mažiau subraižyti restauracijų paviršių, rekomenduojama naudoti plastikinius ar tefloninius rankinius instrumentus. Tyrimo rezultatai rodo, jog beveik puse respondentų (42\%), pastebinčių apnašo pokytị prie skirtingų restauracijų, naudoja tinkamus plastikinius ir tefloninius instrumetus kai dirba prie keramikinių restauracijų paviršiaus. Didžioji dalis nepastebinčių apnašo pokyčio prie skirtingų restauracijų respondentų $(86,2 \%)$ tvirtina, jog naudoja tuos pačius rankinius instrumentus prie keramikinių restauracijų kaip ir prie sveikų dantų (5 pav.).

Dirbant prie dantų implantų rekomenduojama naudoti ne metalinius, o plastikinius, tefloninius ir titaninius, keramikinius instrumentus [8,9] Daugiau nei pusè respondentų $(70,4 \%)$, pastebinčių apnašo pokytị prie skirtingų restauracijų, naudoja tinkamus, plastikinius, keramikinius, titaninius ar tefloninius, instrumentus. Burnos higienistai, kurie nepastebi apnašo pokyčio prie skirtingų restauracijų $(75,9 \%)$, teigè, kad naudotų tinkamus instrumentus, jei jų būtų klinikoje, kurioje dirba (6 pav.).

Glicinas yra mažiausia abrazyvi medžiaga, naudojama poliruojant dantis bei restauracijas oro abrazijos būdu. Ši medžiaga staigiai tirpsta vandenyje ir yra 4 kartus mažiau abrazyvi lyginant su natrio bikarbonatu $[10,11]$. Gauti tyrimo rezultatai rodo, kad daugiau nei pusė respondentų $(51,5 \%)$, pastebinčių apnašo pokytị prie skirtingų restauracijų, naudoja gliciną. Daugiau nei pusè $(54,5 \%)$ tų apklaustujų, kurie teigé, jog nepastebi apnašo pokyčio prie skirtingų restauracijų, nurodo, kad poliruodami restauracijas oro abrazijos būdu naudoja natrio bikarbonatą, 39,4\% (7 pav.).

Svarbu žinoti, kad subraižytas restauracijos paviršius padidina bakterijų adheziją, ir to reikia vengti, vykdant internetinę apklausą buvo klausiama, kam gali turèti itakos subraižytas restauracijos paviršius. Didžioji dalis respondentų (79 \%), pastebinčių apnašo pokytị prie skirtingų restauracijų, mano, kad subraižytas restauracijos paviršius turi įtakos didesnei bakterijų adhezijai, 18,5\% - estetiniam vaizdui ir tik $2,5 \%$ respondentų nurode, kad subraižytas restauracijos paviršius nieko nelemia.

Daugiau nei pusė $(62,1 \%)$ apklaustujų, kurie teigè, jog nepastebi apnašo pokyčio prie skirtingų restauracijų, teigia, jog subraižymas turi įtakos estetiniam vaizdui, $24,1 \%$ - jog subraižymas neturi jokios įtakos restauracijai, o 13,8\% mano, kad tai lemia didesnị bakterijų prikibimą prie restauracijos paviršiaus.

\section{Išvados}

1. Tyrimo rezultatai atskleidè, kad didesniosios dalies burnos higienistų, pastebinčių skirtingą apnašų kaupimąsi prie skirtingų restauracinių medžiagų, nuomonę apie apnašo kaupimąsi nulemia praktinè veikla, literatūros analizè bei konferencijų metu gauta medžiaga. Šie burnos higienistai buvo labiau linkę teigti, kad daugiausia apnašo kaupiasi prie dantų plombų. Didžioji dalis minètų burnos higienistų naudoja tinkamus, plastikinius ir tefloninius instrumentus, dirbdami prie keraminių restauracijų paviršiaus. Didesnioji dalis tyrimo dalyvių, pastebinčių apnašo kaupimąsi prie skirtingų restauracijų, naudoja gliciną, jie labiau buvo linkę teigti, kad atliekant restauracijas tinkamiausias skalerio antgalis yra nerūdijančio plieno.

2. Tyrimo metu buvo nustatyta, kad burnos higienistų, nepastebinčių skirtingo apnašų kaupimosi prie skirtingų restauracinių medžiagų, nuomonei apie apnašo kaupimąsi labiausiai turi įtakos kolegų patirtis. Šie burnos higienistai buvo linkę teigti, kad apnašas labiausiai kaupiasi prie metalo keramikos restauracijų, jie teige, kad nèra skirtumo, su kokiu skaleriu dirbama prie keraminių restauracijų. Šie burnos higienistai nurodè, kad dirbdami prie keramikinių paviršių, naudoja tuos pačius instrumentus kaip ir dirbdami prie sveikų dantų; poliruodami restauracijas oro abrazijos būdu yra linkę dažniau naudoti natrio bikarbonatą.

\section{Literatūra}

1. Özsoy A, Kuşdemir M, Öztürk-Bozkurt F, Toz Akalın T, \& Özcan M. Clinical performance of indirect composite onlays and overlays: 2-year follow up. Journal of Adhesion Science and Technology 2016; 30(16):1808-1818.

https://doi.org/10.1080/01694243.2016.1162460

2. Ay ZY. Interdental hygiene devices for periodontal health [interaktyvus]. JSM Dent 2016; 4(4):1071. [žiūrèta 2018 m. sausio 22 d.]

3. Bösch A, Jung RE, Sailer I, Goran B, Hämmerle F, Hans C \& Thoma DS. Single tooth replacement using dental implants supporting all ceramic and metal based reconstructions: results at 18 months of loading. International Journal of Periodontics \& Restorative Dentistry 2018; 38(2).

https://doi.org/10.11607/prd.2846

4. Checketts MR, Turkyilmaz I, Asar NV. An investigation of the effect of scaling-induced surface roughness on bacterial adhesion in common fixed dental restorative materials. J Prosthet Dent [interaktyvus], 2014; 112(5):1265-70. [žiūrèta 2018 m. Sausio 18 d.]. Prieiga per duomenų bazę PubMed

5. Fron Chabouis H, Prot C, Fonteneau C, Nasr K, Chabreron O, Cazier S, Moussally C, Gaucher A, Khabthani Ben Jaballah I, Boyer R, Leforestier JF, Caumont-Prim A, Chemla F, 39 Maman L, Nabet C, Attal JP. Efficacy of composite versus ceramic inlays and onlays : study protocol for CECOIA randomized 
controlled trial. Trials 2013; Sep 3;14:278. URL. https://doi.org/10.1186/1745-6215-14-278

6. Azam MT, Khan AS, Muzzafar D, Faryal R, Siddiqi SA, Ahmad $\mathrm{R}, \ldots$ \& Rehman IU. Structural, surface, in vitro bacterial adhesion and biofilm formation analysis of three dental restorative composites. Materials 2015; 8(6):3221-3237.

https://doi.org/10.3390/ma8063221

7. Milosevic M. Polymerization mechanins of dental composites advantages and disadventages. Procedia Engineering 2016; $149,313-320$

https://doi.org/10.1016/j.proeng.2016.06.672

8. Chun KA, Kum KY, Lee WC, Baek SH, Choi HW \& Shon WJ. Evaluation of the safety and efficiency of novel metallic implant scaler tips manufactured by the powder injection molding technique. BMC Oral Health 2017; 17(1):110. https://doi.org/10.1186/s12903-017-0396-z

9. Lang MS, Cerutis DR, Miyamoto T \& Nunn ME. Cell attachment following instrumentation with titanium and plastic instruments, diode laser, and titanium brush on titanium, titanium-zirconium, and zirconia surfaces. International Journal of Oral \& Maxillofacial Implants 2016; 31(4).

https://doi.org/10.11607/jomi.4440

10. Lu H, He L, Zhao Y \& Meng H. The effect of supragingival glycine air polishing on periodontitis during maintenance therapy: a randomized controlled trial. PeerJ 2018; 6:e4371. https://doi.org/10.7717/peerj.4371

11. Petersilka GJ. Subgingival air-polishing in the treatment of periodontal biofilm infections. Periodontology 2000; 55(1):124142.

https://doi.org/10.1111/j.1600-0757.2010.00342.x

12. Rashid $\mathrm{H}$. The effect of surface roughness on ceramics used in dentistry: a review of literature. European Journal of Dentistry 2014; 8(4): 571.

https://doi.org/10.4103/1305-7456.143646

\section{ORAL HYGIENISTS' OPINION ABOUT ACCUMULATION OF PLAQUE IN DIFFERENT RESTORATIONS AND WAYS OF PLAQUE REMOVAL E.Valkiūnaitė, A.Varaškevičienė, D.Mačiulienė}

Key words: oral hygienists 'opinion, accumulation of plaque in different restorations, ways of plaque removal.

\section{Summary}

No one can avoid the process of accumulation of plaque in oral cavity. If it is not removed in time, it becomes harmful and can cause diseases of teeth and gums. As dental diseases progress, it becomes more difficult to repair the defects by using sealants, that is why dentists often need to do the prosthetic or dental implantation work. In the case of restorative materials, the plaque in the oral cavity accumulates further - both in the teeth and in the restorations. When removing the plaque during professional hygiene, the oral hygienist should pay attention to what restorations are in the oral cavity of the patient and what measures are suitable for removing the plaque. By choosing the wrong remedies, there is a risk that after the procedure the plaque will accumulate even more due to the scratches of the restoration surfaces. During the study it is analyzed the opinion of the oral hygienists about accumulation of plaque on different restorations, what measures are used to remove it, whether the patient is given counseling on how to stop the accumulation of plaque and whether any remedies are recommended to use at home.

Correspondence to: daiva.maciuliene@go.kauko.lt

Gauta 2019-01-21 